
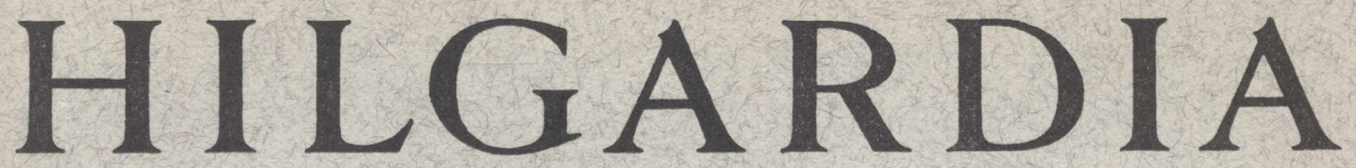

A Journal of Agricultural Science Published by the California Agricultural Experiment Station

\title{
RESPONSES OF A PLANT \\ TO SOIL-MOISTURE CHANGES AS SHOWN BY GUAYULE
}

\author{
F. J. VEIHMEYER \\ and \\ A. H. HENDRICKSON
}

THIS COMPLETES VOLUME 30

UNIVERSITY OF CALIFORNIA - BERKELEY, CALIFORNIA 
From March, 1943, to April, 1946, field and tank studies on responses of guayule to different soil-moisture conditions were conducted at Davis, California.

Three types of treatment were begun in the spring of the second season: irrigation when the soil moisture in the top 3 feet was reduced to about 14 per cent; irrigation when the soil moisture was reduced to about the permanent wilting percentage (PWP); and no irrigation.

Results from the final sampling of the field plots when the crop was harvested showed clearly that the irrigated treatments produced larger plants than the unirrigated plots which were allowed to remain at the PWP for a long period. In rubber content, the lowest percentage was found in the treatment where the soil moisture was kept relatively high. The treatment in which the soil moisture was reduced to a much lower level several times during the season produced slightly, but not significantly, larger plants and a significantly higher percentage of rubber than did the treatment in which a relatively high moisture content was maintained. All treatments increased markedly in percentage of rubber during the winter. The unirrigated treatment produced the highest rubber content of all.

Results in the tank tests were in agreement with those in the field. The largest plants were produced in the tanks in which the soil moisture was allowed to be reduced to about the PWP, but not to remain there for an appreciable time. Maintenance of the moisture above a high level by frequent irrigations did not increase the growth of plants over those in the drier soil.

The data presented indicate that soil moisture between the field capacity and the PWP is readily available to guayule plants. 


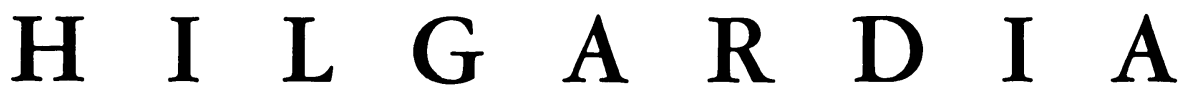

A Journal of Agricultural Science Published by

the California Agricultural Experiment Station

VoL. 30

MAY, 1961

No. 20

\section{RESPONSES OF A PLANT TO SOIL-MOISTURE CHANGES AS SHOWN BY GUAYULE}

\section{F. J. VEIHMEYER ${ }^{2}$ and A. H. HENDRICKSON ${ }^{3}$}

\section{INTRODUCTION}

Availability of soil moisture to plants has been widely discussed. Experiments by the present writers have led to the conclusion that moisture is readily available to supply water for all plant functions so long as the moisture content of the soil that is in contact with the absorbing portion of the roots is not reduced to the permanent wilting percentage (PWP). Opposing opinions have argued that, theoretically, water cannot be readily available to plants over the range from field capacity to the PWP because of the excessive amount of energy required to remove water from soil that is near the PWP. Veihmeyer and Hendrickson $(1950)^{4}$ and Veihmeyer (1956) have shown that such is not the case. Lack of water for transpiration and others needs of the plant's growth, however, may result from slow movement of roots into moist soil from a region of dry soil. Also, changes may be induced within the plant by low soil-moisture conditions, and these may limit the plant's ability to absorb water. Whether the latter factors are limiting conditions in the uptake of water by the plants can only be answered satisfactorily by empirical trials.

Reviews by Richards and Wadleigh (1952), Veihmeyer and Hendrickson (1950), and Veihmeyer (1956) present the main arguments as to whether or not soil moisture is readily available to plants throughout the range from field capacity to the PWP.

The present study is confined to the responses of guayule (Parthenium argentatum) to different soil-moisture conditions.

\section{REVIEW OF THE LITERATURE}

Wadleigh, Gauch, and Magistad (1946) conducted experiments to determine the effect of salinity on plant responses. These workers used guayule plants grown in 10-gallon steel drums holding about 100 pounds of dry soil. Three

${ }^{1}$ Submitted for publication February 16, 1960.

${ }^{2}$ Professor of Irrigation and Irrigation Engineer, Emeritus, Davis.

${ }^{3}$ Pomologist, Emeritus, in the Experiment Station; Davis.

${ }^{4}$ See "Literature Cited" for citations referred to in the text by author and date. 
irrigation treatments were given: one in which the soil moisture was intended to be maintained at a relatively high level $(\mathrm{L})$; one in which the moisture was expected to be allowed to fall to the permanent wilting percentage $(\mathrm{H})$; and one in which the soil moisture was kept at a high level during the first part of the observation period (March 1 to July 9) and then allowed to fall to the PWP during the latter part (July 9 to December 1). This last series was designated L-H. Each treatment was replicated three times. Nine drums were used-three for each nonsalt treatment $(O)$ and six to which varying amounts of salt were added. The nonsalt series, in which we are particularly interested, were designated $\mathrm{OL}, \mathrm{OH}$, and $\mathrm{OL}-\mathrm{H}$.

These authors point out (p. 24) that the $\mathrm{OH}$, the one in which the soil moisture was allowed to fall to the PWP, "developed a high stress-20 atmospheres-before being irrigated. Yet these plants at no time showed evidence of wilting." The authors also mention that xeromorphic species, such as guayule, may stand even high-tension values before showing evidence of wilting. Again, they state "it is evident that the high diffusion-pressure deficit developed in the soil moisture during the last day of the irrigation interval of the $\mathrm{OH}$ series would effect an increase in diffusion-pressure deficit within the tissue fluids of the plant. The development of such a stress would definitely inhibit growth processes" (p. 26).

It is evident, then, that the $\mathrm{OH}$ plants had reached the PWP. The plants in the OL-H series were at the PWP during the latter part of the season. The plants in the salt-treated series at low soil moisture were also at the PWP for some time. Therefore, in these experiments we only have the comparative growth of plants kept supplied with readily available water, that is, water between field capacity and PWP, and those which were allowed to reach the PWP and stay at that moisture condition long enough for growth to be affected. There were no intermediate treatments. Baver (1956), in referring to these experiments, states that they "show fairly conclusively that plant growth is reduced rather rapidly as the soil moisture stress is increased." Our understanding of the work does not indicate that such a conclusion is justified.

Hunter and Kelley (1946) give the results of field irrigation studies on guayule. These experiments were carried on near Shafter and near Crows Landing in the San Joaquin Valley of California. Five water application treatments were given. Treatment 1 was intended to maintain the soil moisture above the field capacity at all times. In treatment 2 , soil was to be irrigated when the moisture content at the 12-inch depth fell to a value of 75 per cent of the range between the field capacity and the PWP. In treatment 3 , soil was irrigated when the moisture content at the 12-inch depth fell to the value of 33 per cent of the range between field capacity and PWP. Treatment 4 received no irrigation after the initial heavy irrigation at the beginning of April. Treatment 5 was not irrigated. The soil in treatments 4 and 5 was depleted of moisture early in the season.

Thus, two treatments, 1 and 2 , were supplied with readily available water through the period of observation, but the others, 3,4 , and 5 , were allowed to reach the PWP and remain there for an appreciable time.

The soil in treatment 3, in experiments at Shafter, was at the PWP in all 
depths of soil sampled in the latter part of July, and remained there for some time. Again in late August and September, the PWP was reached in all depths of soil. Therefore, treatment 3 was without readily available water for considerable time during the season. Treatments 4 and 5 were depleted of readily available water after the middle of June, and remained in that condition thereafter.

About the same conditions prevailed in the plots at Crows Landing. Here again only treatments 1 and 2 were supplied with readily available water at all times.

Directing our attention only to the data for the yield of shrubs per acre, the sampling data of August showed that, statistically, there were no significant differences at the 1 per cent level for treatments 1, 2, and 3 at either location. The yields from 4 and 5 were significantly lower, as might be expected because of the depletion of readily available soil moisture early in the season. The growth of shrubs at both locations was not significantly different between treatments 1 and 2 . The November sampling data show no significant differences between 1 and 2 . However, the differences were significant between 1,2, and 3,4, and 5. On the March sampling of the following year there were differences only between yields from the 4 and 5 treatments and those from 1, 2, and 3. Hence, it is clear that differences in growth of guayule plants in those experiments were affected only when the soil moisture was reduced to the PWP and remained there for an appreciable period.

Hunter and Kelley concluded that at Shafter "on the sandy soil, the highest yields of shrub and rubber per acre were given by the plots maintained at the higher levels of moisture; on the silty clay loam at Crows Landing, the highest rubber yields were produced on the plots having the lowest moisture levels." They failed to point out, however, that the low moisture-level plots were allowed to dry out to the PWP. Actually, there were wide differences in soil moisture between plots in treatments 1,2 , and 3 , the latter treatment being reduced to the PWP in most of the 8-foot depths of soil sampled. Yet in only one case, the November sampling on the plots on the sandy loam soil, was there significant difference in yields between treatment 3 and treatments 1 and 2 . It would seem more appropriate to say that the growth of shrubs was not affected until the soil moisture was reduced to the PWP.

Kelley, Hunter, and Hobbs (1945) report the results of experiments with nursery-grown guayule, in which five different irrigation treatments were given. The treatments were designed to maintain soil-moisture stresses in the following ranges: treatment I, between field capacity and a tension of $850 \mathrm{~cm}$ of water at the 6 -inch depth; treatment II, with a tension above 850 $\mathrm{cm}$ of water at the 12-inch depth; treatment III, between field capacity and the PWP at the 6-inch depth; treatment IV, between field capacity and the PWP at the 12-inch depth; and treatment V, no irrigation after the plants were well established. Changes in the soil-moisture content were followed by means of oven-dried samples, tensiometers, and Bouyoucos blocks.

The soil-moisture records show that these soil-moisture conditions were not maintained. Only in treatment I was the soil moisture kept above the PWP at all times. The soil in treatment II was reduced to the PWP on about August 17, again on August 25, about September 7 in all but the 8- to 12-inch 
depth, and in all depths on about September 20, remaining there for the rest of the season.

The soil-moisture conditions in treatment III were more severe than in treatment II. Here the soil reached the PWP in all depths on about August 22 and again on about September 12, and remained there for the rest of the season. The soil-moisture conditions in treatment IV were not markedly different from those in treatment III except that the soil in treatment IV was at the PWP in all depths sampled on about August 8 and remained there until about August 19. Again, on about September 14, all of the soil was depleted of readily available moisture. No soil-moisture records are given for treatment $\mathrm{V}$.

Growth of the plants in treatment I, the only one in which the soil moisture was not reduced to the PWP, was not greater than any of the other treatments on July 10 nor on July 23. In fact, the growth was greater on the dryer soil plots than on treatment I. On August 21 there were no significant growth differences between I, II, and III. On September 28 the difference in growth between I and II was significant at the 5 per cent but not at the 1 per cent level. On October 19 there was significant difference in growth between (in favor of) treatments I and III, IV, and V, but not between I and II. These results are surprising in view of the fact that all of the treatments except I were depleted of readily available water for some time during the season. Indeed it is remarkable that the plants in treatments IV and V grew so well under the severe moisture conditions to which they were subjected.

Traub, Slattery, and McRary (1946) used samples of plants from the plots in the experiment of Hunter and Kelley (1946). These authors speak about high, intermediate, and low moisture stress, probably with the intent to indicate that differences would occur within the plant if the soil moisture were maintained above different levels between field capacity and PWP. Actually, no intermediate condition was maintained in these experiments. Only treatment I, as explained before, was supplied with readily available water at all times. The soil in the other treatments was at the PWP at various times during the season. The implication that differences would be produced by variations in the amount of readily available water is not substantiated in this instance nor in the experiments of Hunter and Kelley (1946).

Tingey and Foote (1947) concluded that fall-irrigated and fertilized guayule plants gave yields significantly higher than those under any other treatments. Data given are insufficient to permit an analysis of the soil-moisture conditions in the various treatments used in the experiments. It is mentioned that on November 6 the moisture in the first foot of soil in the fallirrigated plots averaged about 3 per cent and was only slightly above that percentage to a depth of 5 feet. The PWP of the soil in these plots is said to have been between 2 and 3.5. It would seem, therefore, that not all of the soil in the fall-irrigated plots had readily available water. Here, again, the comparison should be made only between the yields from plots in which the soil moisture was maintained above the PWP and those in which the soil moisture was depleted to the PWP and probably remained there for some time. The data in this paper do not indicate what the effect of variation in soil moisture between field capacity and PWP might have been. Allowing the plants to suf- 
fer for lack of water by reduction of the soil moisture to the PWP, of course, would be expected to influence the plant.

Benedict, McRary, and Slattery (1947) raised nursery guayule plants in wooden boxes, $14 \times 14$ inches square and 20 inches deep. Some of the boxes were said to be supplied with abundant water. In others, the soil was under low-moisture stress for two months followed by two months of drought. In still others, plants were grown under low-moisture stress for four months, followed by four months under high-moisture stress. Another treatment, featured a 10-month period of low-moisture stress, followed by four months of a high one.

The fact that the resistance of the Bouyoucos plaster-of-Paris blocks reached such a high value in the dry-soil boxes indicates that the soil was allowed to reach the PWP, and remained there for an appreciable time. Hence, we have only two conditions of moisture with which to make comparisons, one in which the soil was kept above the PWP and one in which the soil moisture was reduced to the PWP and allowed to remain there for considerable periods of time.

Benedict (1950) reports the effect of high and low soil moisture on seedling guayule. The plants were grown in half-gallon glazed crocks in the greenhouse. This paper does not contain data on the soil moisture in the crocks other than to say that a high level of soil moisture was obtained by watering daily. The low soil-moisture treatment was maintained by allowing the soil to dry out until a weight was reached which indicated that the soil moisture was close to the wilting percentage. In view of the other work of this author, referred to previously, in which the same procedure was used as here, it is reasonable to assume that the soil in the low-moisture crocks was at the PWP for appreciable periods of time.

Tingey and Foote (1946) studied the effect of irrigation versus nonirrigation on guayule replants. Not enough soil moisture data are given in this paper to permit an analysis of the effect on growth responses of the variation in soil moisture between field capacity and PWP.

Tingey (1952) reports the results of field trials with guayule. He used three irrigation treatments: heavy, in which the plots were irrigated when approximately 50 per cent of the available soil moisture in the first foot had been depleted; light, in which all the readily available moisture had been depleted to a depth of 3 feet before irrigation; and no irrigation. No soilmoisture records are given. It is not possible, therefore, to judge how closely the program was followed. A series of soil samplings showing the moisture condition in the light-irrigated plots would disclose whether the soil was at the PWP and for how long in each foot of depth. In 1944 these plots received three irrigations, and in 1945, two irrigations. The yield of shrub in tons per acre in 21 months was 4.8 for the heavy-irrigated treatment and 4.4 for the light-irrigated one. Corresponding yields in 33 months were 6.92 and 6.00 , respectively. The growth of shrub on the unirrigated plots was, of course, much lower, probably because of the long period within which the soil was at the PWP. Data in this paper are insufficient to permit judging the probable effect on growth of plants of variation of soil moisture between the field capacity and the PWP. 


\section{RESPONSES OF GUAYULE TO DIFFERENT SOIL-MOISTURE CONDITIONS}

Two types of studies, field and tank, were conducted at Davis, California, from March, 1943, to April, 1946.

\section{Field Studies}

In the field studies the plantings were made with seedlings obtained from the Special Guayule Research Project of the United States Department of Agriculture. The planting was divided into 30 plots, each plot consisting of eight rows of 65 plants. Rows were 28 inches apart, and the plants were $18 \frac{1}{2}$ inches apart in the rows. Because of unfavorable soil and climatic conditions during and after planting, considerable replanting was necessary in order to secure a full stand. The soil on which the experimental area was located was described as a Yolo sandy loam, the characteristics of which are given below.

\begin{tabular}{|c|c|c|}
\hline $\begin{array}{l}\text { DEPTH } \\
\text { feet }\end{array}$ & $\begin{array}{c}\text { MOISTURE } \\
\text { EQUIVALENT }\end{array}$ & PWP \\
\hline$\ldots \ldots \ldots \ldots$ & 22.6 & 10.6 \\
\hline $1-2 \ldots \ldots \ldots \ldots \ldots \ldots \ldots \ldots$ & 20.2 & 10.0 \\
\hline$\ldots \ldots \ldots \ldots$ & 17.7 & 9.4 \\
\hline Mean... & 20.2 & 10.0 \\
\hline$\ldots \ldots \ldots \ldots \ldots$ & 15.9 & 9.1 \\
\hline$\ldots \ldots \ldots \ldots \ldots \ldots \ldots$ & 13.6 & 8.4 \\
\hline $5-6$. & 11.0 & 7.3 \\
\hline$\ldots \ldots \ldots \ldots$ & 13.5 & 8.3 \\
\hline
\end{tabular}

The plots were irrigated frequently enough to keep the plants supplied with readily available moisture during the first season, except in a few cases where the soil moisture was reduced to about the PWP in the top foot late in September.

Differential irrigation treatment was started in the spring of the second season. The experimental area was reduced by the exclusion of two plots (numbers 1 and 16) at the south end of the planting because of an unsatisfactory stand of plants. Four other plots (numbers 4, 6, 20, and 21) were eliminated because of weak, uneven growth, possibly due to injury following the use of a spray applied for weed control. The remaining 24 plots were divided into three treatments of eight plots each, randomized as shown in figure 1. The treatments were as follows: A, irrigated when the soil moisture in the top 3 feet was reduced to about 14 per cent; B, irrigated when the soil moisture was reduced to about the PWP ; and D, not irrigated. Thus, the soil in treatment A was kept at a relatively high moisture content.

In the second season, treatment $\mathrm{A}$ was irrigated eight times during the period between May 24 and October 2. Treatment B was irrigated four times between June 23 and September 11, with no water applied after September 11. Treatment $D$ was not irrigated. Treatments $A$ and $B$ received an average total of 48.4 and 26.7 acre-inches per acre, respectively, by irrigation. 


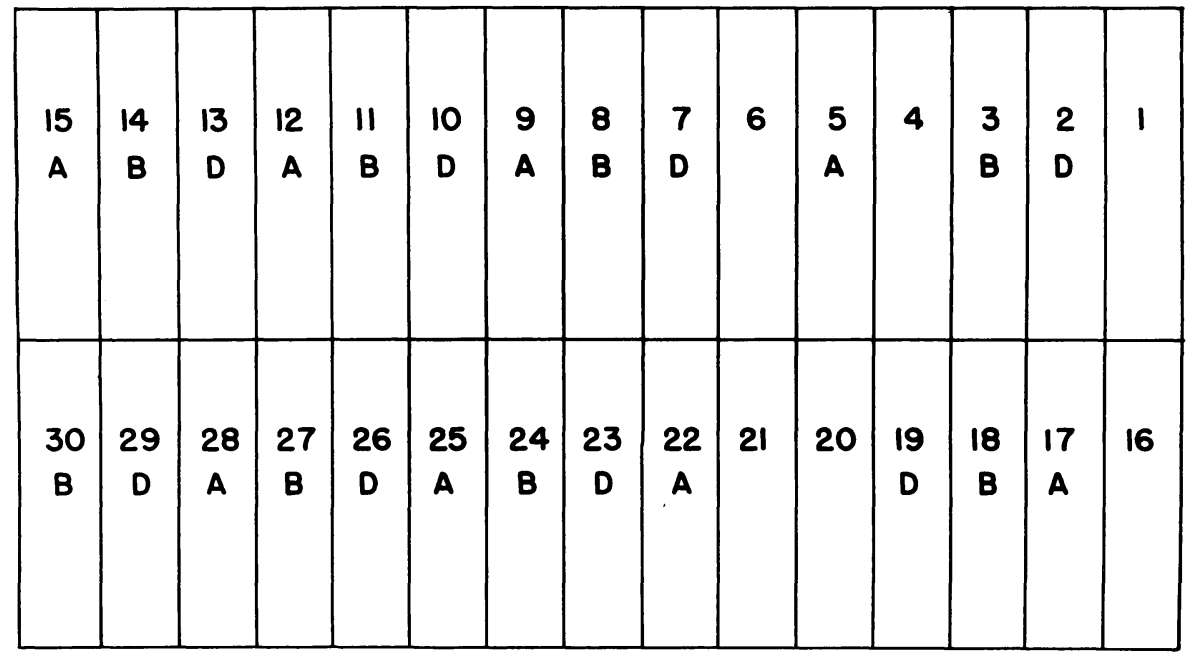

Fig. 1. Arrangement of plots. Treatment A irrigated when soil moisture was reduced to about 14 per cent in the top 3 feet; B irrigated when soil moisture reached, but was not allowed to remain at, the PWP; D, not irrigated.

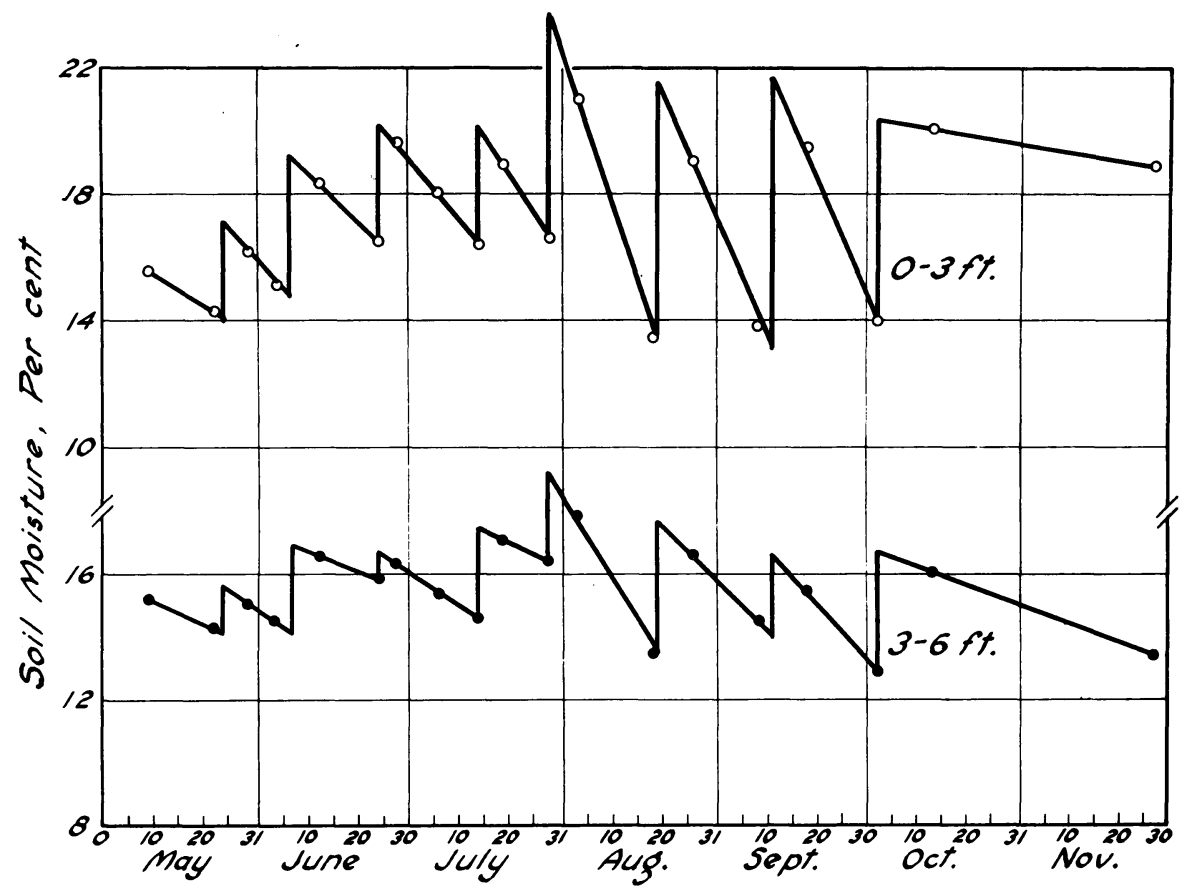

Fig. 2. Soil-moisture record for treatment A during the second season. 
The records for the average moisture content of the top 3 feet and the 3 - to 6 -foot depths for treatment $\mathrm{A}$ are shown in figure 2 for the second season. Those for treatment B are given in figure 3 , and for treatment D in figure 4 . There were wide differences in soil moisture in the three treatments. The four irrigations given in the second season to the plots in treatment $\mathrm{B}$ were applied just before the average soil moisture in both 3-foot depths reached the PWP. The soil in treatment D reached the PWP in the top foot late in June; in the 4- to 6-foot level, inclusive, about the middle of August.

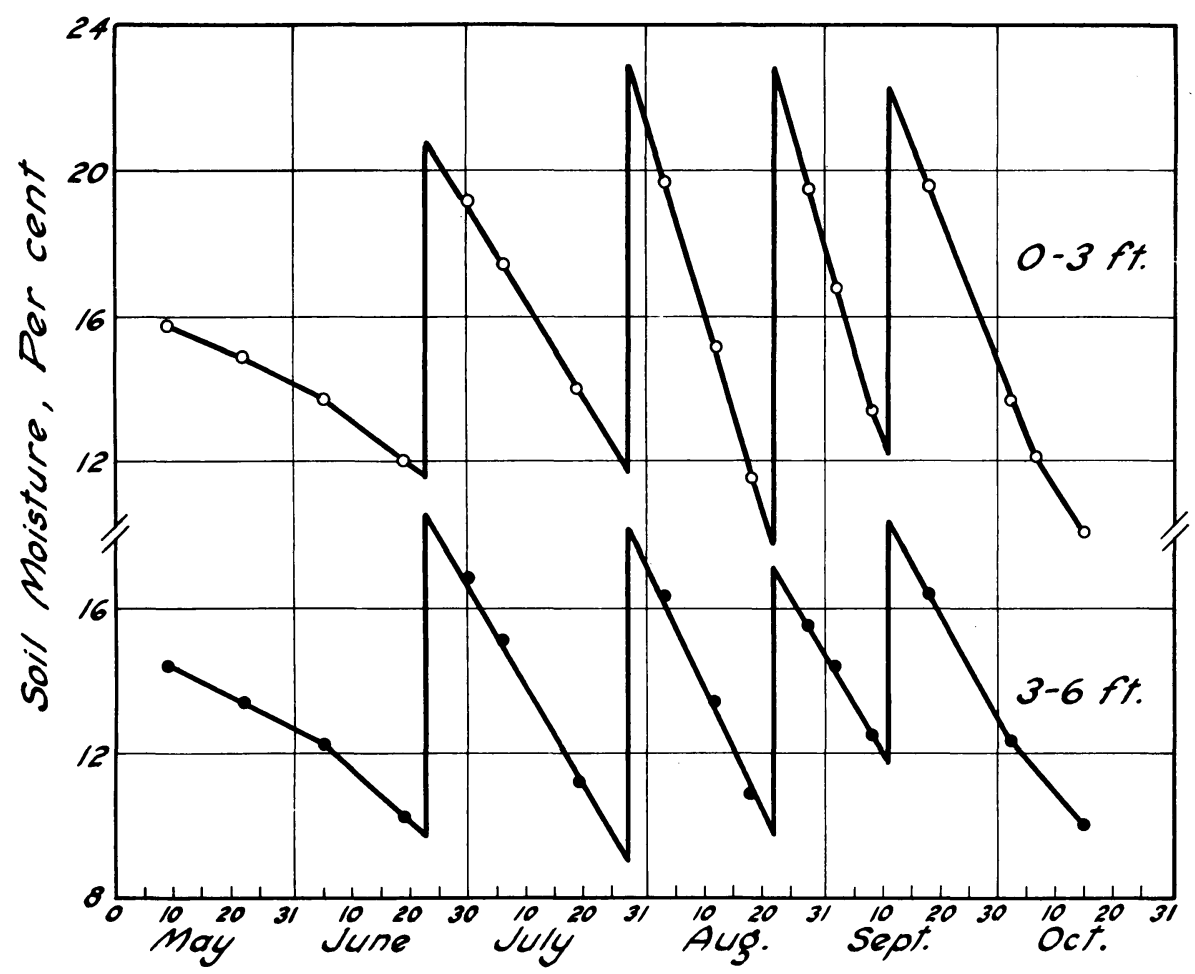

Fig. 3. Soil-moisture record for treatment B during the second season.

During the third season, treatment A was irrigated 11 times between May 11 and September 17, the first three irrigations being applied at intervals of about 15 days while the remaining eight were given about every 10 days beginning with July 9 . No samples were taken because the soil was too wet to permit adequate sampling. Previous experience indicated that, with such frequent irrigation, the soil moisture was maintained well above 14 per cent.

Treatment B was irrigated five times between May 23 and September 5 at intervals of about 26 days. Treatment A received 73.6 acre-inches per acre, and $\mathrm{B}, 48.5$. Treatment $\mathrm{D}$ was not irrigated. As in the second year, the irrigations for treatment $\mathrm{B}$ were applied just before the average soil-moisture contents in both the upper and lower 3 feet of soil reached the PWP. The soil- 
moisture record for treatment D in 1945, the third season, was substantially the same as that for the second season, 1944.

Three plants, judged to be average, were dug from each plot on February 19 of the third season, according to the method suggested by the investigators in the Emergency Guayule Project at Salinas. The plants were carefully lifted from the soil, and the soil was removed from the roots. The average fresh weights of the plants from treatments A and B were slightly, but not significantly, larger than those from treatment $\mathrm{D}$. The dry weights showed

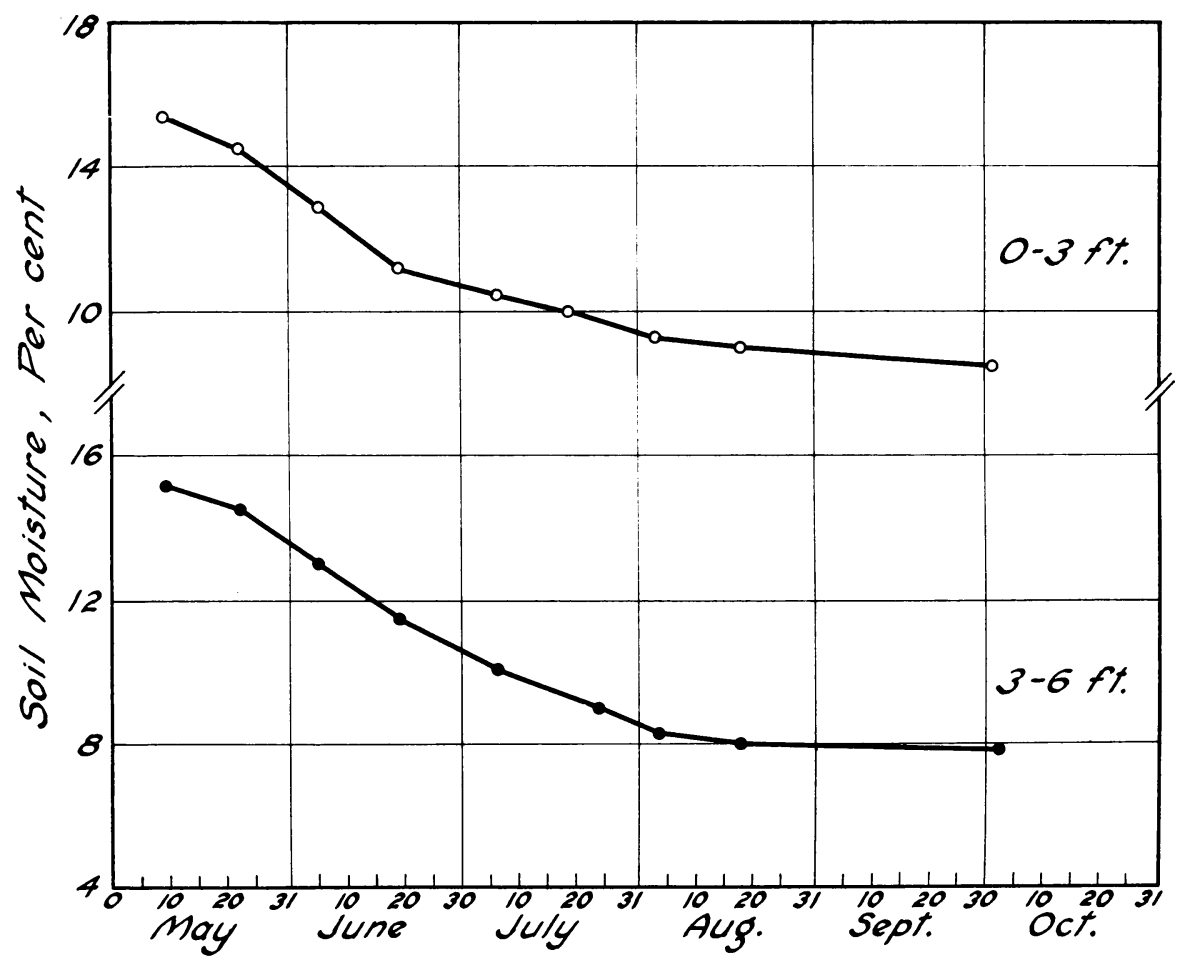

Fig. 4. Soil-moisture record for treatment $\mathrm{D}$ during the second season.

corresponding differences that also were without statistical significance. In percentage of rubber, the treatment $\mathrm{D}$ showed a significantly higher percentage than treatments $\mathrm{A}$ and $\mathrm{B}$, but the yields of rubber per plant showed no significant difference among treatments. Apparently, the higher percentage of rubber in treatment $D$ was offset by the smaller sizes of the plants. The results are given in table 1.

The second sampling of plants for weights and rubber contents was made on October 17 at the end of the third season. The results are given in table 2. The irrigated treatments (A and B) produced larger plants than did treatment $\mathrm{D}$, but only the plants from $\mathrm{B}$ were significantly larger than those in treatment $\mathrm{D}$. The plants in treatment $\mathrm{B}$ were also larger than those in $\mathrm{A}$, but not significantly so. The dry weights show essentially similar differences. 
TABIJE 1

GUAYULE PLANTS DUG FOR WEIGHTS AND RUBBER CONTENTS

(February 19, 1945, beginning of the third season.)

\begin{tabular}{|c|c|c|c|c|c|c|}
\hline Treatment & $\begin{array}{l}\text { Av. fresh wt., } \\
3 \text { plants } \\
\text { per plot }\end{array}$ & $\begin{array}{l}\text { Av. dry wt. } \\
3 \text { plants } \\
\text { per plot }\end{array}$ & $\begin{array}{c}\text { Moisture, } \\
\text { dry-wt. } \\
\text { basis }\end{array}$ & $\begin{array}{l}\text { Moisture, } \\
\text { fresh-wt. } \\
\text { basis }\end{array}$ & $\begin{array}{c}\text { Rubber con- } \\
\text { tent, dry-wt. } \\
\text { basis }\end{array}$ & $\begin{array}{l}\text { Total rubber, } \\
3 \text { plants } \\
\text { per plot }\end{array}$ \\
\hline & $g m$ & $g m$ & per cent & per cent & per cent & $g m$ \\
\hline A. & $649 \pm 43.8^{*}$ & $339 \pm 23.6$ & 91.4 & 47.7 & $2.78 \pm 0.04$ & $28.2 \pm 0.71$ \\
\hline B. & $714 \pm 68.3$ & $369 \pm 31.1$ & 93.5 & 48.3 & $2.76 \pm 0.07$ & $30.4 \pm 1.18$ \\
\hline D.... & $551 \pm 46.4$ & $288 \pm 25.9$ & 91.3 & 47.7 & $3.37 \pm 0.15$ & $29.3 \pm 1.97$ \\
\hline
\end{tabular}

* Probable error.

TABLE 2

GUAYULE PLANTS DUG FOR WEIGHTS AND RUBBER CONTENTS (October 17, 1945, near the end of the third season.)

\begin{tabular}{|c|c|c|c|c|c|c|}
\hline Treatment & $\begin{array}{c}\text { Av. fresh } \\
\text { wt., } 3 \text { plants } \\
\text { per plot }\end{array}$ & $\begin{array}{l}\text { Av. dry } \\
\text { wt., } 3 \text { plants } \\
\text { per plot }\end{array}$ & $\begin{array}{c}\text { Moisture, } \\
\text { dry-wt. } \\
\text { basis }\end{array}$ & $\begin{array}{l}\text { Moisture, } \\
\text { fresh-wt. } \\
\text { basis }\end{array}$ & $\begin{array}{c}\text { Rubber } \\
\text { content, } \\
\text { whole plant, } \\
\text { dry-wt. } \\
\text { basis }\end{array}$ & $\begin{array}{l}\text { Total rubber, } \\
3 \text { plants } \\
\text { per plot }\end{array}$ \\
\hline & $g m$ & $g m$ & per cent & per cent & per cent & $g m$ \\
\hline A. & $1,035 \pm 54.0^{*}$ & $591 \pm 31.0$ & 75.1 & 42.9 & $1.87 \pm 0.07$ & $35.4 \pm 1.78$ \\
\hline B. & $1,145 \pm 44.1$ & $634 \pm 24.7$ & 80.4 & 44.6 & $2.65 \pm 0.12$ & $53.9 \pm 1.74$ \\
\hline D....... & $859 \pm 37.3$ & $493 \pm 16.8$ & 74.2 & 42.6 & $4.53 \pm 0.37$ & $66.0 \pm 3.81$ \\
\hline
\end{tabular}

* Probable error.

TABLF 3

GUAYULE PLANTS, FINAL HARVEST, APRIL 11, 1946

(35 months after planting.)

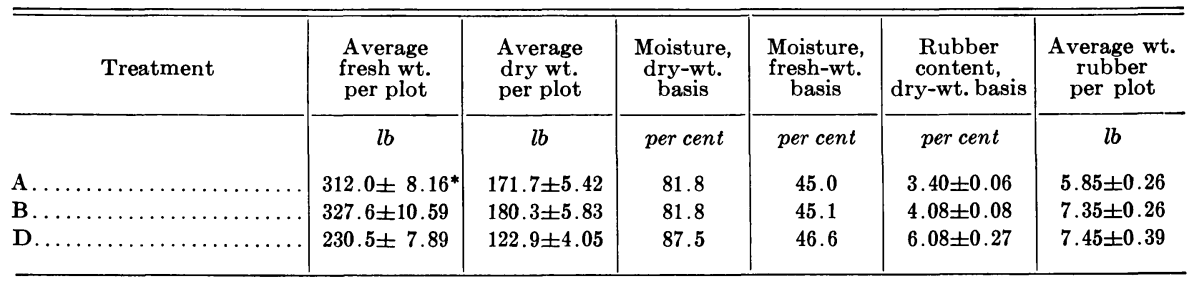

* Probable error.

During the interval between the first and second samplings (February 19, 1945, and October 17, 1945), the irrigated treatments decreased slightly in percentage of rubber, while the unirrigated treatment increased (calculated on dry-weight basis). In the October sampling, treatment $D$ had a significantly higher percentage of rubber than either A or B. Treatment B was also significantly higher in yield than $\mathrm{A}$.

The yield of rubber from treatment $D$ was significantly larger than that from $A$ in spite of the smaller size of the plants. This probably was caused by the reduction of the soil moisture to the PWP early in the season. The differ- 
ence between $\mathrm{D}$ and $\mathrm{B}$ approached significance (odds 20 to 1). Treatment $\mathrm{B}$ also produced a significantly greater yield of rubber than did $\mathrm{A}$.

The entire planting was dug on April 11 of the following year. Two rows of plants surrounding each plot were discarded to avoid the "border" effect. The remainder was weighed, and 12 plants were taken from each plot at random for drying and rubber analyses. The yields, expressed in pounds per plot, are given in table 3 . In general, the differences in fresh weights corresponded fairly well with the fresh weights of the samples taken the previous October.

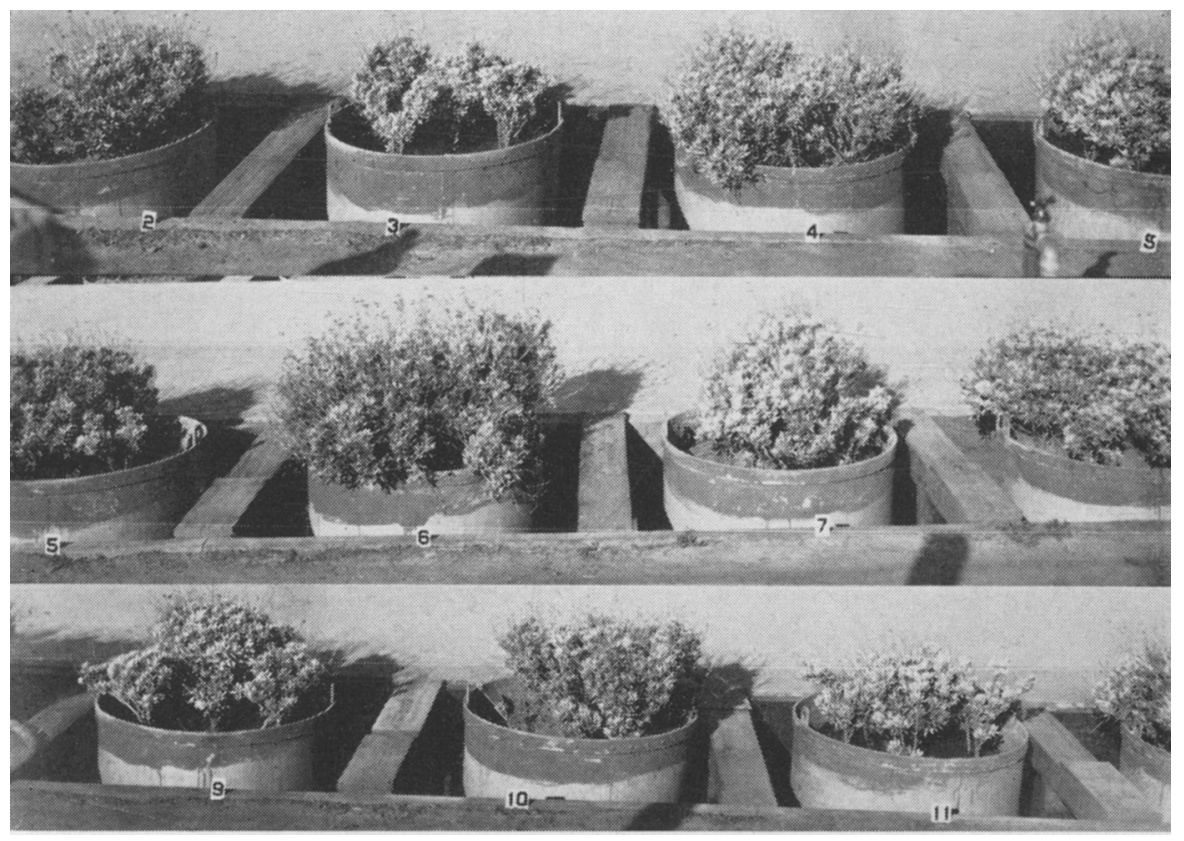

Fig. 5. Guayule in odd-numbered tanks was given wet treatment, in which soil moisture was kept at high level. In even-numbered tanks, soil moisture was reduced to the PWP before irrigation.

The samples from the final harvest showed that the irrigated plots produced significantly larger plants, both in the fresh and the dry weights, than did the unirrigated treatment $\mathrm{D}$. The plants in treatment $\mathrm{B}$ were also larger than those in treatment $\mathrm{A}$, but not significantly so, in spite of the fact that the soil moisture content in treatment A was higher than that in B.

Throughout the growing season, the percentage of rubber increased in all treatments between October 17, 1945, and April 11 of the following year. Treatment $\mathbf{D}$ had a significantly higher rubber percentage than either $\mathbf{A}$ or B. Treatment B was also significantly higher than A.

In the final results, treatment $D$ produced a greater weight of rubber than either A or B, but significantly greater than A only. Treatment B, which received only about half as much water as A during the final growing season, also produced a significantly greater weight of rubber than did A. 


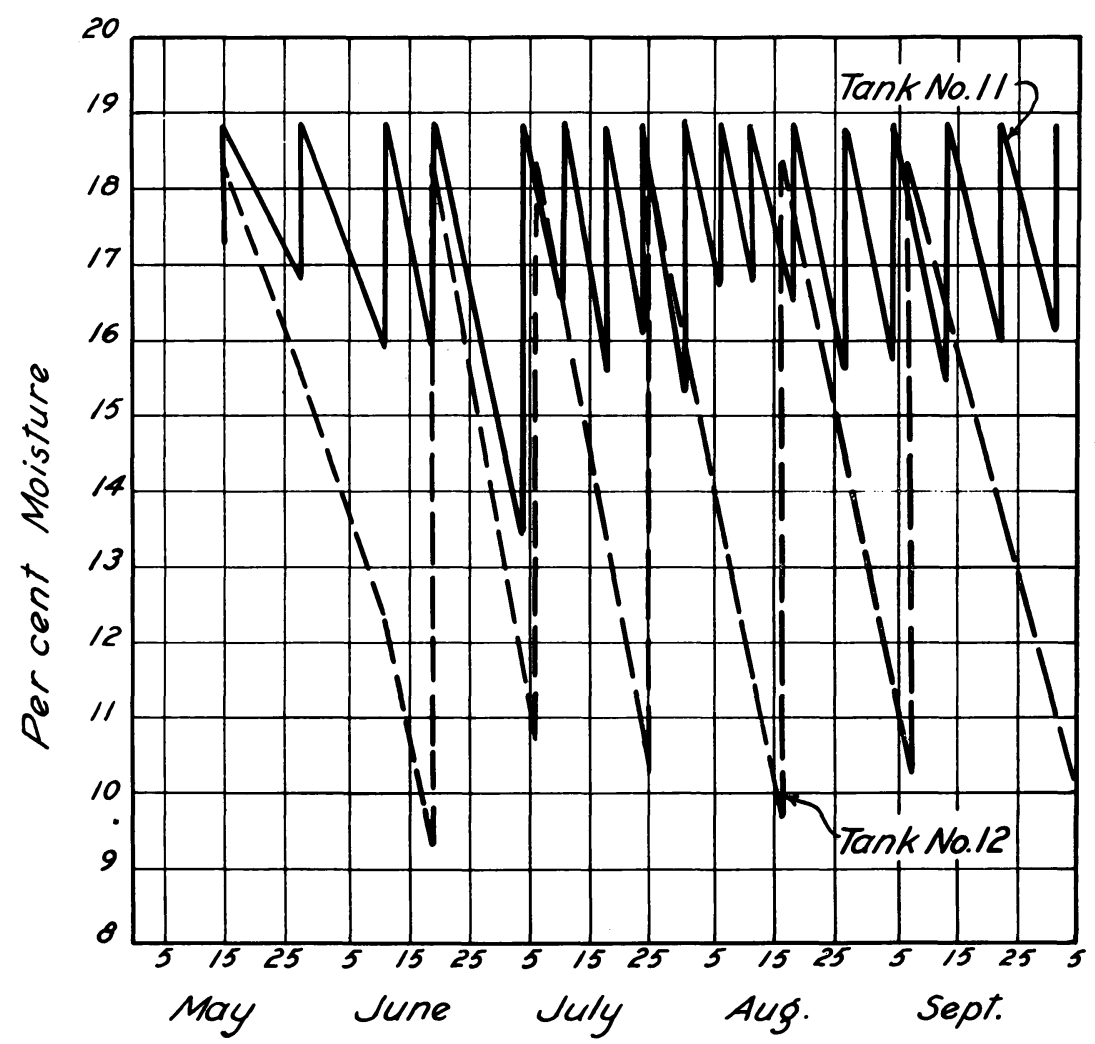

Fig. 6. Soil moisture in tanks 11 and 12, second season. Average minimum soil-moisture content reached in tank 11, 15.9, water used, 912 pounds; in tank 12, 10.0, water used, 941 pounds.

\section{Tank Experiments}

Experiments with guayule plants grown in tanks of about 1-ton capacity, filled with soil similar to that used in the field trials, were carried on simultaneously with the latter. Twelve tanks were used. Six were irrigated frequently (the odd-numbered ones) so that the minimum soil-moisture content was kept at a high level. In the even-numbered tanks, the soil moisture was allowed to be reduced to, or very close to, the PWP before each irrigation.

Figure 5 shows a portion of the installation at the end of the second season's growth. Table 4 records amounts of water used and the average minimum moisture content to which the soil was reduced. The large amount of water used by the plants in tank number 6 was due to the large size of the plants (fig. 5).

Figure 6 shows the variations in soil moisture in tanks 11 and 12 for the second season, and figure 7 gives the results for tanks 7 and 8 for the third 


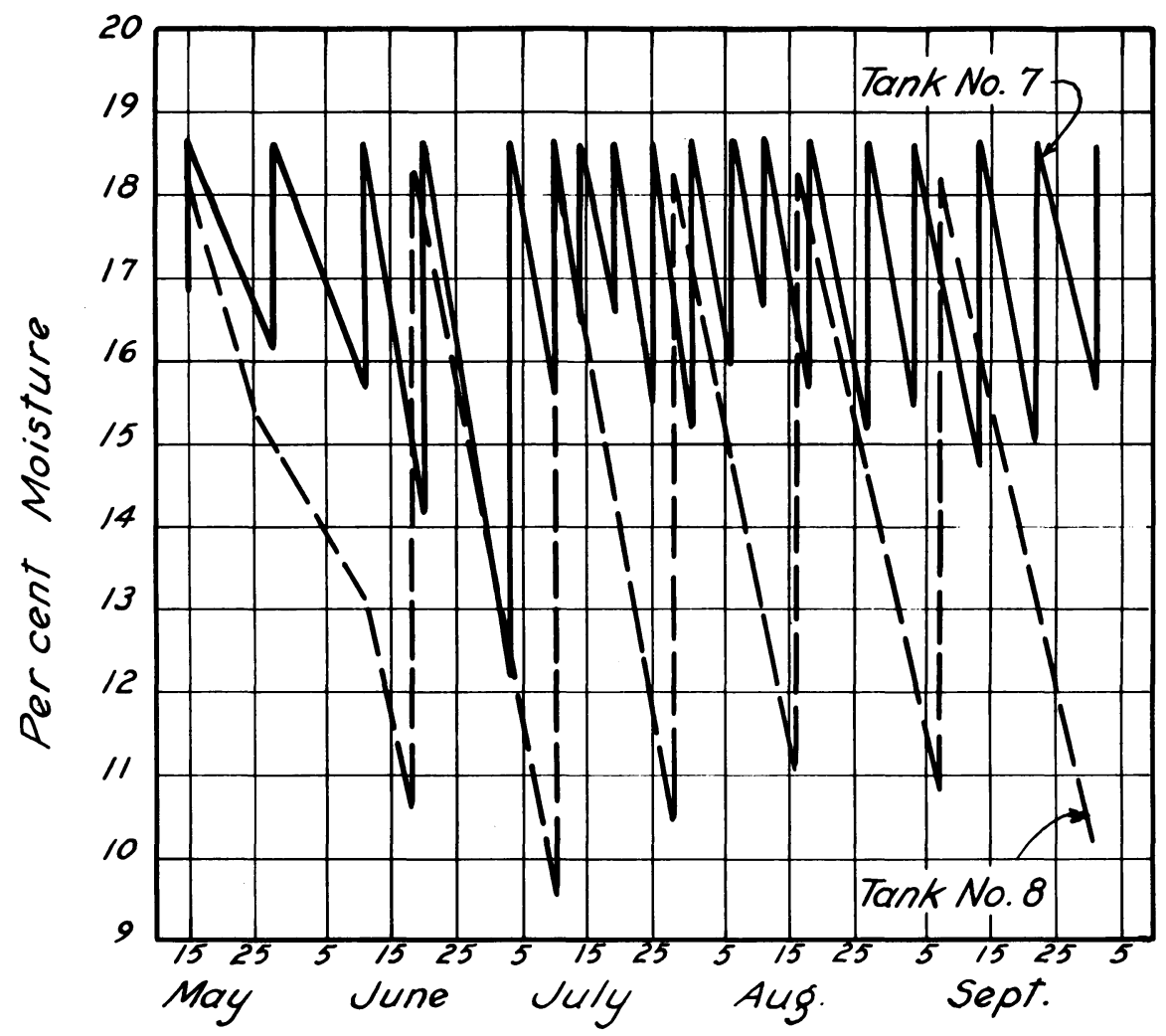

Fig. 7. Soil moisture in tanks 7 and 8 , third season. Average minimum soil-moisture content reached in tank 7, 15.5, water used, 904 pounds; in tank 8, 10.5, water used, 876 pounds.

season. These records are similar to those for the other tanks used in the experiment. Much wider differences in soil moisture were brought about in the even-numbered tanks than in the odd-numbered ones. In the former, all of the readily available water was exhausted before irrigation.

The plants were removed after having grown in the tanks for 35 months. As many of the roots as possible were washed from the soil, and the weights of tops and roots were recorded (table 5). Here, the plants in the evennumbered tanks, which corresponded in soil-moisture conditions with those in treatment $\mathrm{B}$ in the field, were larger than those in the odd-numbered series, which were under soil-moisture conditions similar to those in treatment $\mathrm{A}$ in the field. The slightly larger plants in the even-numbered tanks corresponding to the treatment B field experiments, as compared with those in the odd-numbered tanks, are apparent in figure 5 . 
TABLE 4

WATER USED BY GUAYULE PLANTS GROWN IN TANKS

\begin{tabular}{|c|c|c|c|c|c|c|c|}
\hline \multirow[b]{2}{*}{ Tank number } & \multicolumn{4}{|c|}{ Second season (1944) } & \multicolumn{3}{|c|}{ Third season (1945) } \\
\hline & $\begin{array}{l}\text { Number } \\
\text { of irriga- } \\
\text { tions }\end{array}$ & $\begin{array}{c}\text { Moisture } \\
\text { equivalents }\end{array}$ & $\begin{array}{l}\text { Average } \\
\text { minimum } \\
\text { soil-moisture } \\
\text { content } \\
\text { reached } \\
\text { by soil }\end{array}$ & $\begin{array}{l}\text { Total use } \\
\text { of water* }\end{array}$ & $\begin{array}{c}\text { Number } \\
\text { of irriga- } \\
\text { tions }\end{array}$ & $\begin{array}{c}\text { Average } \\
\text { minimum } \\
\text { soil-moisture } \\
\text { content } \\
\text { reached } \\
\text { by soil }\end{array}$ & $\begin{array}{l}\text { Total use } \\
\text { of water* }\end{array}$ \\
\hline & & & per cent & $l b$ & & per cent & $l b$ \\
\hline . & 24 & 17.87 & 15.41 & 989 & 16 & 14.84 & 813 \\
\hline 3. & 22 & 18.08 & 15.54 & 950 & 17 & 15.15 & 846 \\
\hline 5 . & 25 & 18.66 & 16.19 & 1,088 & 16 & 15.22 & 936 \\
\hline 7. & 29 & 18.62 & 16.30 & 1,148 & 18 & 15.46 & 904 \\
\hline & 24 & 18.94 & 16.24 & 1,171 & 17 & 15.62 & 969 \\
\hline $11 \ldots$ & 23 & 18.88 & 16.44 & 1,032 & 17 & 15.90 & 912 \\
\hline Mean.... & 24.5 & 18.51 & 16.02 & 1,063 & 16.8 & 15.37 & 896.7 \\
\hline $2 \ldots$ & 9 & 18.00 & 10.39 & 1,084 & 6 & 10.92 & 800 \\
\hline $4 \ldots \ldots \ldots \ldots$ & 9 & 18.10 & 10.40 & 1,188 & 6 & 10.45 & 780 \\
\hline $6 \ldots \ldots \ldots \ldots$ & 16 & 18.30 & 10.75 & 2,103 & 9 & 10.22 & 1,269 \\
\hline $8 \ldots \ldots \ldots$ & 10 & 18.23 & 10.50 & 1,464 & 6 & 10.45 & 876 \\
\hline $10 \ldots \ldots \ldots$ & 9 & 18.10 & 10.57 & 1,193 & 6 & 10.77 & 650 \\
\hline $12 \ldots \ldots \ldots$ & 8 & 18.39 & 10.16 & 1,260 & 6 & 10.00 & 941 \\
\hline Mean. & 10.2 & 18.19 & 10.46 & 1,382 & 6.5 & 10.47 & 886.0 \\
\hline
\end{tabular}

* The record for the second season is for 178 days, that for the third season, 143 days.

\section{DISCUSSION}

The severe soil-moisture conditions in the field experiments in treatment D (unirrigated) are reflected in the small size of the plants as measured by either the fresh or dry weights (table 4). The D plants were smaller than those from $\mathrm{A}$, the high-moisture treatment, and $\mathrm{B}$, in which the soil moisture fluctuated through a wide range, but significantly smaller only than those from $\mathrm{B}$. On the other hand, the rubber percentage of the plants from treatment $\mathrm{D}$ was significantly higher than those from A and B. Probably this was due to the adverse soil-moisture conditions in treatment $\mathrm{D}$, which caused a build-up of the reserve material. In total yield of rubber from the thirdseason (October) sampling, D produced significantly more rubber than A, while the difference betwen $\mathrm{D}$ and $\mathrm{B}$ approached significance.

The results from the final sampling of the field plots when the crop was harvested showed clearly that the irrigated treatments produced larger plants than the unirrigated plots which were allowed to remain at the PWP for a long period. In rubber content, the lowest percentage was found in the treatment where the soil moisture was kept relatively high. The B treatment, in which the soil moisture was reduced to a much lower level than in A several times during the season, produced slightly, but not significantly, larger plants, and a significantly higher percentage of rubber than did the A treatment that was kept at a relatively high moisture content. All treatments increased markedly in percentage of rubber during the winter. The unirrigated treatment produced the highest rubber content of all. 
TABLE 5

GUAYULE FROM TANKS, HARVESTED FEBRUARY 22, 1946

(End of experiment, 35 months after planting.)

\begin{tabular}{|c|c|c|c|c|c|}
\hline Tank number & $\begin{array}{c}\text { Number of } \\
\text { plants }\end{array}$ & $\begin{array}{l}\text { Fresh wt., } \\
\text { whole plants }\end{array}$ & $\begin{array}{c}\text { Fresh wt., } \\
\text { roots }\end{array}$ & $\begin{array}{c}\text { Dry wt. } \\
\text { tops }\end{array}$ & $\begin{array}{c}\text { Dry wt., } \\
\text { roots }\end{array}$ \\
\hline & & \multicolumn{4}{|c|}{ Narrow fluctuations in soil-moisture contents } \\
\hline & & $g m$ & $g m$ & $g m$ & $g m$ \\
\hline $1 \ldots$ & 7 & 763 & 183 & 319 & 85 \\
\hline $3 \ldots$ & 6 & 733 & 179 & 307 & 95 \\
\hline 5.. & 6 & 964 & 215 & 433 & 115 \\
\hline $7 .$. & 5 & 1,052 & 217 & 498 & 116 \\
\hline 9. & 6 & 915 & 243 & 399 & 130 \\
\hline 11. & 6 & 792 & 175 & 340 & 87 \\
\hline Totals. . & 36 & 5,219 & 1,212 & 2,296 & 628 \\
\hline \multirow[t]{2}{*}{ Av, per plant. } & .. & $145.0 \pm 9.9^{*}$ & $33.7 \pm 1.8$ & $63.8 \pm 5.4$ & $17.4 \pm 1.1$ \\
\hline & & \multicolumn{4}{|c|}{ Wide fluctuations in soil-moisture contents } \\
\hline 2. & 6 & 844 & 210 & 360 & 101 \\
\hline & 6 & 1,065 & 209 & 490 & 103 \\
\hline $6 \ldots$ & 5 & 1,659 & 320 & 814 & 180 \\
\hline $8 \ldots$ & 7 & 1,057 & 242 & 500 & 131 \\
\hline $10 \ldots$ & 4 & 1,030 & 241 & 458 & 129 \\
\hline $12 \ldots \ldots \ldots \ldots \ldots \ldots \ldots$ & 5 & 1,053 & 243 & 479 & 142 \\
\hline Totals. & 33 & 6,708 & 1,465 & 3,101 & 786 \\
\hline Av. per plant. & .. & $203.3 \pm 19.2^{*}$ & $44.4 \pm 3.7$ & $94.0 \pm 10.3$ & $23.8 \pm 2.2$ \\
\hline
\end{tabular}

* Probable error in each case.

A total yield of rubber, treatment $A$, which was kept at a high moisture content, gave the lowest yield of rubber. Yields from D were significantly larger than those from A, but not B, at final harvest. The increased production of rubber by allowing the soil moisture to remain at the PWP for an appreciable time is in accord with the work of others reported above.

The sizes of plants grown in tanks were in agreement with those in the field. The largest plants were produced in the tanks in which the soil moisture was allowed to be reduced to about the PWP, but not to remain there for an appreciable time. Maintenance of the moisture above a high level by frequent irrigations did not increase the growth of plants over those in the drier soil. The slopes of the curves in figures 6 and 7 show about uniform rates of extraction of moisture whether the soil moisture was high or low.

This fact is further substantiated when the use of water by the plants in tanks 4 and 7 is plotted against the difference in evaporation between black and white atmometers, as shown in figure 8. It has been shown that there is a very high correlation between these quantities (Halkias, Veihmeyer, and Hendrickson, 1955). The use of water as measured by the loss in weight of the tank includes both transpiration and evaporation directly from the soil surface. The plants covered the soil, and the latter loss was very small. Tank 


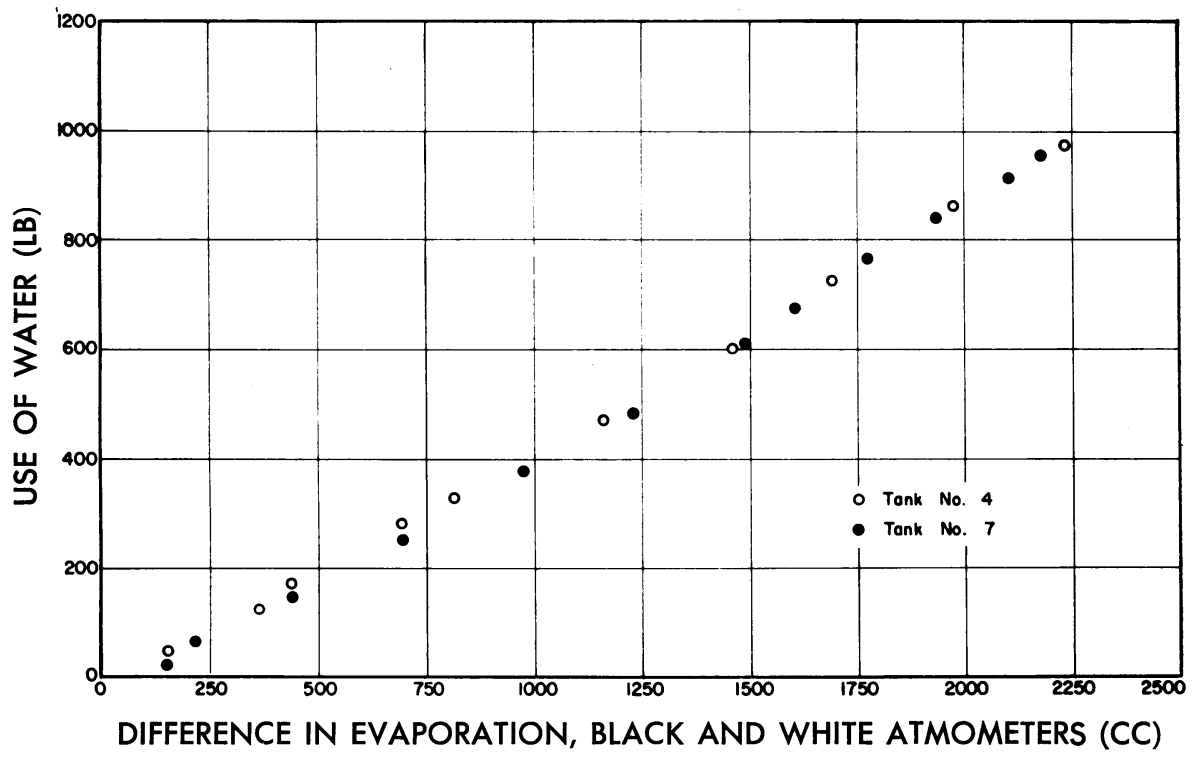

Fig. 8. Use of water by guayule plants, and difference in evaporation between black and white atmometers. Tank 7 was irrigated 29 times, tank 4, only nine times. Difference in soil moisture in the tanks was very great.

7 was irrigated 29 times (table 4 ), and tank 4, nine times. This figure is taken from a previous publication (Veihmeyer and Hendrickson, 1957), to which the reader is referred for a more detailed discussion of the relation of soil moisture to use of water by crops.

\section{SUMMARY}

In a three-year trial with guayule at Davis, California, plants that were unirrigated during the last two years of the experiment, and received water only from winter rains, produced the most rubber.

All treatments increased in rubber content between the October and April samplings.

The percentage of rubber was higher at the end of the experiment than at the end of the second year.

The growth of plants in the field under high soil-moisture conditions was not greater than that in the treatments in which the soil moisture was reduced to about the PWP before irrigation. Neither the use of water by the plants in tanks nor their growth was increased at high moisture levels over those in treatments which allowed the soil moisture to drop almost to the PWP. The slopes of the water-extraction curves by guayule plants in tanks, the regression lines of water use, and the difference in evaporation between black and white atmometers show that water is equally available for transpiration between the field capacity and PWP.

The data presented here show that soil moisture between the field capacity and the PWP is readily available to guayule plants. 


\section{ACKNOWLEDGMENT}

We wish to acknowledge the assistance of Dr. H. G. Reiber in making the analyses of rubber in the plants taken from our plots.

\section{LITERATURE CITED}

BAVER, L. D.

1956. Soil physics (3d ed.). New York: John Wiley \& Sons.

BENEDICT, H. M.

1950. Factors affecting the accumulation of rubber in seedling guayule plants. Bot. Gaz. 112: 86-95.

Benedict, H. M., W. L. McRary, and M. C. Slattery

1947. Response of guayule to alternating periods of low and high moisture stresses. Bot. Gaz. 108: 535-49.

Halkias, N. A., F. J. Veihmeyer, and A. H. Hendrickson

1955. Determining water needs for erops from climatic data. Hilgardia 24(9): 207-33.

HUNTER, A. S., and OMER J. KeLLEY

1946. The growth and rubber content of guayule as affected by variations in soil moisture stresses. Jour. Amer. Soc. Agron. 38: 118-34.

Kelley, O. J., A. S. HunTER, and C. H. HobBS

1945. The effect of moisture stress on nursery-grown guayule with respect to the amount and type of growth and growth response on transplanting. Jour. Amer. Soc. Agron. 37: 194-216.

Richards, L. A., and C. H. WADLEIGH

1952. Soil water and plant growth. In: Soil physical conditions and plant growth. Amer. Soc. Agron. Monograph II: 73-251.

TingeY, D. C.

1952. Effect of spacing, irrigation, and fertilization on rubber production in guayule sown directly in the field. Jour. Amer. Soc. Agron. 44: 298-302.

TingeY, D. C., and W. H. Foote

1946. Effect of irrigation on the resumption of growth of guayule transplants. Jour. Amer. Soc. Agron. 38: 896-904.

Tingey, D. C., and Wilson Foote

1947. Effect of plant spacing, free irrigation, and fertilization on rubber production during the winter in 1-year-old guayule. Jour. Amer. Soc. Agron. 39: 234-39.

Traub, H. P., M. C. SlaATTery, and W. I. McRary

1946. The effect of moisture stress on nursery-grown guayule with reference to changes in reserve carbohydrates. Amer. Jour. Bot. 33: 699-705.

VeIHMEYeR, F. J.

1956. Soil moisture. Handbuch der Planzenphysiologie, Bd. III: 64-123.

VeIHMEYER, F. J., and A. H. HeNDRICKSON

1950. Soil moisture in relation to plant growth. Ann. Rev. Plant Physiol. 1: 285-304.

1957. Use of black and white atmometers for measuring the use of water by crops, evaporation and solar energy. International Commission on Irrigation and Drainage. Third Congress, San Francisco, California, 1957.

Wadleigh, C.H., H. G. GaUCh, and O. C. Magistad

1946. Growth and rubber accumulation in guayule as conditioned by soil salinity and irrigation regime. U. S. Dept. Agr. Tech. Bul. 925. 

The journal Hilgardia is published at irregular intervals, in volumes of about 600 pages. The number of issues per volume varies. Subscriptions are not sold. The periodical is sent as published only to libraries, or to institutions in foreign countries having publications to offer in exchange.

You may obtain a single copy of any issue free, as long as the supply lasts; please request by volume and issue number from:

\section{Agricultural Publications$$
207 \text { University Hall }
$$$$
2200 \text { University Avenue }
$$$$
\text { Berkeley 4, California }
$$

The limit to nonresidents of California is 10 separate issues on a single order. A list of the issues still available will be sent on request. 


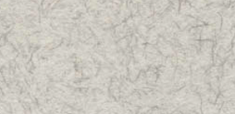

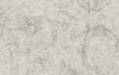

$\lim _{2} x^{2}=$

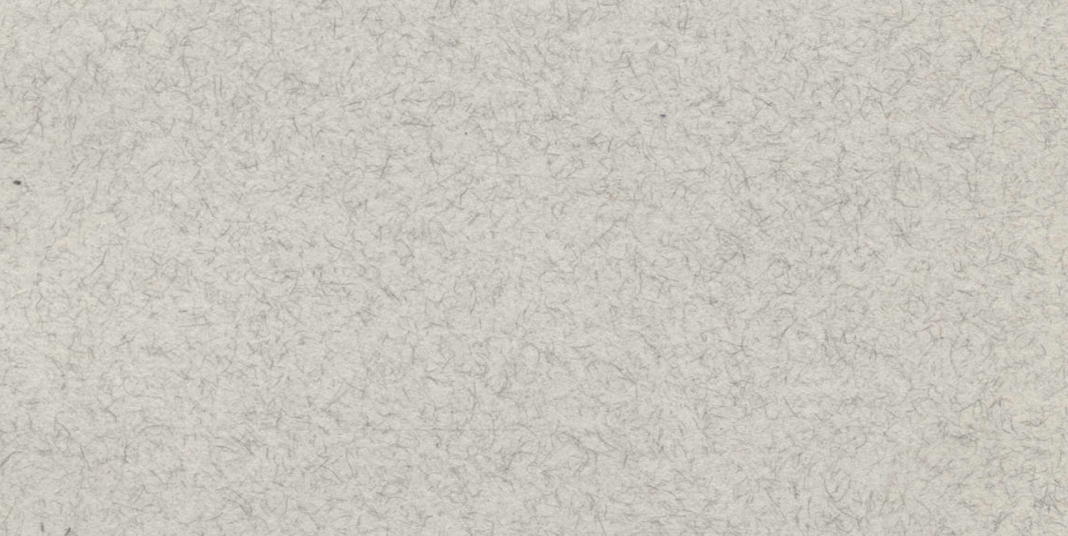

$(2,4)$ 